the time taken by a molecule in travelling across the cubical enclosure.

The argument drawn by Campbell in favour of his suggestion from the expression $\frac{1}{2} C V^{2}$ for electrical energy is not convincing, and is possibly misleading. The more fundamental formula is $\frac{1}{2} Q V$, where $Q$ is quantity of electricity and $V$ is potential. This form suggests that Callendar was right in linking entropy to "matter of heat" as the equivalent of $Q$, while $V$ corresponds to temperature.

University,

$$
\text { H. S. Allen. }
$$

St. Andrews.

Feb. 3.

${ }^{2}$ Campbell, Ian D., NATURE, 151, 138 (1943).

2 Allen and Maxwell, "Text-Book of Heat", Part 2, Chap. 30 (Macmillan, 1939). Reference mav also be made to Part 1 , Chap. 23, dealing with "Physical Magnitudes and their Measurement".

s wheeler, S. G. "Entropy as a Tangible Conception" (Crosby Lockwood, 1921). Allen, H. S., NATURE, 109, 404 (1922).

‘ Brown, G. B., Phil. Mag., 33, 543 (1942).

\section{Newt Larvæ in Brackish Water}

THE statement in Miss H. Spurway's interesting observations on the above subject ${ }^{1}$, that it is generally believed that amphibian larvæ are not found in salt or brackish water, is interesting because the brackish 'slacks' or pools between the west Lancashire coastal dunes from Ainsdale to Formby have long been inhabited by breeding specimens of the common smooth newt, common frog, common toad, and natterjack toad. The natterjack is, of course, a wellknown breeding inhabitant of brackish estuary waters; many hundreds breed at Ainsdale; and I have seen its tadpoles in the tide line salt marsh at the Dee mouth between Hilbre Point and Hoylake, Cheshire, and at other estuaries.

Incidentally, mention of the natterjack toad reminds me that a species inhabits Gilbert White's famous great pond at Wolmer, although not numerously, but he did not list it in his time.

47 Woodsorrel Road,

Eric Hardy.

Liverpool, 15. Jan. 28.

${ }^{1}$ NATURH, 151, 109 (1943).

\section{Water Content of Medusæ}

I HAVE read with considerable interest the recent communication from Dr. L. H. Hyman dealing with the water content of medus ${ }^{1}$. My apologies are due to Dr. Hyman for having failed to refer to his communication of $1938^{2}$ in my own contribution to NATURE $^{3}$; but when I was doing the work and also when writing up the account it was impossible for me to get hold of the proper references, since the greater part of the library has been removed from the Laboratory at Plymouth. However, the omission shows the close agreement in our independent results.

I do not propose to discuss the merits of our different methods beyond stating that, in the displacement method ${ }^{4}$, the living specimens of Aurelia aurita were neither rinsed in distilled water nor drained, since in this method the living specimens are not removed from their environment. According to Dr. Hyman the water content of Aurelia aurita in seawater of $3 \cdot 2$ per cent salinity was 96 per cent, while I found it to be $\mathbf{9 6 \cdot 5 6}$ per cent in sea-water of the same salinity.

Reference to the figures given by Dr. Hyman in $1938^{2}$ will show how close the agreement is between the determinations made on both sides of the Atlantic, and one trusts that the figure $99 \cdot 8$ per cent for the water content as originally recorded by Gortner ${ }^{5}$ can now be allowed to sink into obscurity and no longer find its way into current text-books either of an advanced or elementary nature. One would expect the water content to vary slightly in different specimens, but its value lies between 96 and $96 \cdot 6$ per cent, and it varies slightly with the salinity.

Further, in medusæ living in water of more than 3 per cent salinity, the water content ranges from 94 to $96 \cdot 6$ per cent. In freshwater medusæ it may be higher. 99.8 per cent is clearly an impossible figure for the water content of any animal living in ordinary sea-water, though admittedly such an animal might be composed of $99 \cdot 8$ per cent sea-water.

The Laboratory,

A. G. Lowndes.

Citadel Hill,

Plymouth.

${ }^{1}$ Hyman, L. H., NATURE, 151, 140 (1943).

'Hyman, L. H., Science, 87, 166 (1938).

s Lowndes, A. G., Nature, 150, 234 (1942).

- Lowndes, A. G., J. Mar. Biol. A88., 25, 555 (1942).

"Gortner, R. A., "Outlines of Biochemistry" (2nd Ed. John Wiley, New York, 1938), p. 276.

\section{A Middle Pleistocene Discovery in the Anglo-Egyptian Sudan}

Artefacts in type similar to the Chellean, early Acheulean, and Acheulean of the fourth stage. of East Africa have been found in situ in ironstone gravel only $5 \mathrm{~m}$. above the present flood plain on the banks of the Khor Abu Anga, a left-bank tributary which joins the Nile a kilometre downstream from the confluence of the Blue and White Niles. Late Acheulean implements and a few artefacts of Levallois type apparently associated with them have also been found on the surface ; and it is hoped before long to find them in situ too.

Similar assemblies have also been found farther downstream on the left bank between Khor Abu Anga and the Sabaloka gorge.

These discoveries mark an important stage in the study of the history of the Nile basin. Besides showing that erosion levels had nearly reached those of the present day long before the Sebilian silts were deposited below Wadi Halfa, and that a pre-Sebilian lake extending as far as the Sabaloka hills is most improbable, they indicate the way by which further study will yield a more complete view of the history of the two Niles, and will link up the succession of events in East Africa and the Belgian Congo with those in Egypt and the Mediterranean region generally.

Evidence has also been found in favour of regarding the ironstone gravels of the district as of sedimentary detrital origin, derived from the local Nubian series. The previous view ${ }^{1}$ that these were lateritic 'marram' and indicated a comparatively late 'lateritic' climate is without foundation", as no trace of general 'lateritization' of the included boulders or artefacts can be found, nor is there any lateritization of subjacent deposits, whether rock (Nubian series) or gravels and sands. G. ANDrEw.

Office of Commissioner for Archæology A. J. Arkeli. and Anthropology,

P.O. Box 178, Khartoum. Nov. 11.

' Sandford, Quart. J. Geol. Soc., 81, 367 (1935).

2 cf. Edmonds, Geol. Mag., 79, 29 (1942). 